\title{
Novel guggulsterone derivative GG-52 inhibits NF- $\kappa$ B signaling in intestinal epithelial cells and attenuates acute murine colitis
}

\author{
Jung Mogg Kim ${ }^{1, *}$, Hyoun Woo Kang ${ }^{2, *}$, Mi Yeon Cha ${ }^{1}$, Doyoung Yoo ${ }^{1}$, Nayoung Kim², In-Kyoung Kim², \\ Jeounghun $\mathrm{Ku}^{3}$, Sunil $\mathrm{Kim}^{3}$, Sang-Ho Ma ${ }^{4}$, Hyun Chae Jung ${ }^{2}$, In Sung Song ${ }^{2}$ and Joo Sung Kim ${ }^{2}$
}

We already showed that the plant sterol guggulsterone has been reported to inhibit nuclear factor- $\kappa \mathrm{B}(\mathrm{NF}-\kappa \mathrm{B})$ signaling in intestinal epithelial cells (IECS) and to attenuate dextran sulfate sodium (DSS)-induced colitis. This study investigates the anti-inflammatory effects of novel guggulsterone derivatives on IEC and preventive and therapeutic murine models of DSS-induced colitis. Novel guggulsterone derivates with high lipophilicity were designed and four derivates, including GG-46, GG-50B, GG-52, and GG-53, were synthesized. Two guggulsterone derivatives, GG-50B and GG-52, significantly inhibited the activated NF- $\kappa B$ signals and the upregulated expression of interleukin-8 (IL-8) in COLO 205 cells stimulated with tumor necrosis factor- $\alpha$ (TNF- $\alpha$ ). Pretreatment with GG-50B and GG-52 attenuated the increased $1 \kappa B$ kinase (IKK) and $I_{\kappa} \mathrm{B} \alpha$ phsophorylation induced by TNF- $\alpha$. In preventive and therapeutic models of murine colitis, administration of GG-52 significantly reduced the severity of DSS-induced colitis, as assessed by disease activity index, colon length, and histology. In contrast, GG-50B did not show a significant reduction in the colitis severity. Moreover, the efficacy on attenuating colitis by GG-52 was comparable to that by sulfasalazine or prednisolone. These results indicate that the novel guggulsterone derivative GG-52 blocks NF- $\kappa$ B activation in IEC and ameliorates DSS-induced acute murine colitis, which suggests that GG-52 is a potential therapeutic agent for the treatment of inflammatory bowel diseases.

Laboratory Investigation (2010) 90, 1004-1015; doi:10.1038/labinvest.2010.54; published online 1 March 2010

KEYWORDS: guggulsterone derivatives; inflammatory bowel disease; murine colitis; NF- $\kappa \mathrm{B}$

Inflammatory bowel disease (IBD) is a complex group of chronic relapsing inflammatory disorders of the intestinal tract. IBD comprises two prototypes, ulcerative colitis and Crohn's disease. Although the etiology of IBD remains unknown, current evidence strongly suggests that IBD arises from a disruption of mucosal immune homeostasis in genetically susceptible individuals, resulting in altered processing of enteric antigens, pathogenic T-cell activation, and chronic inflammation. ${ }^{1,2}$ Despite the significant advances in understanding the underlying genetic basis and pathogenesis of the diseases, no drugs used to treat IBD have a non-relapsing cure rate, and few non-toxic therapeutic options are currently able to modulate intestinal inflammation. Therefore, the discovery of new and specific therapies for IBD is still a challenge. ${ }^{3}$
The intestinal epithelium serves as a barrier between luminal triggers and the host. Impaired barrier function may lead to increased uptake of luminal antigens that promote mucosal inflammation. ${ }^{4}$ The intestinal barrier is formed by epithelial cells and junctional complexes including tight junctions. Defects of the barrier are directly related to increased intestinal epithelial permeability and uptake of luminal antigens that result in IBD. ${ }^{5-7}$ Therefore, drugs that can reverse defects of the barrier need to be developed.

Activation of the proinflammatory gene transcriptional program in intestinal epithelial cells (IECs) when challenged by the bacterial products, including lipopolysacchride, or various inflammatory cytokines such as tumor necrosis factor- $\alpha(\mathrm{TNF}-\alpha)$ and interleukin (IL)- $1 \beta$, is associated with

\footnotetext{
${ }^{1}$ Department of Microbiology, Hanyang University College of Medicine, Seoul, Korea; ${ }^{2}$ Department of Internal Medicine and Liver Research Institute, Seoul National University College of Medicine, Seoul, Korea; ${ }^{3}$ Department of Biomedical Engineering, Hanyang University, Seoul, Korea and ${ }^{4}$ Central Research Institute, Choongwae Pharma, Hwasung, Korea

Correspondence: Dr JS Kim, MD, PhD, Department of Internal Medicine and Liver Research, Seoul National University College of Medicine, 28 Yongon-dong, Chongnogu, Seoul 110-744, Korea.

E-mail: jooskim@snu.ac.kr

*These two authors contributed equally to this work.

Received 2 September 2009; revised 11 January 2010; accepted 21 January 2010
} 
acute or chronic intestinal inflammation. ${ }^{8}$ Activation of transcription factor nuclear factor- $\kappa \mathrm{B}$ (NF- $\kappa \mathrm{B}$ ) leads to upregulation of the expression of proinflammatory genes involved in IBD development. ${ }^{9}$ In addition, the increase in intestinal epithelial tight junction permeability requires NF- $\kappa \mathrm{B}$ activation. ${ }^{10}$ Therefore, NF- $\kappa \mathrm{B}$ activation in IECs seems to be strongly associated with IBD, suggesting that modulation of NF- $\kappa$ B signaling could be a potential target for the treatment of IBD., ${ }^{9,11,12}$

Recently, we showed that guggulsterone [4,17(20)-pregnadiene-3,16-dione] blocks NF- $\kappa \mathrm{B}$ signaling pathway and attenuates acute murine colitis. ${ }^{13}$ Guggulsterone is an active compound extracted from the gum resin of the tree Commiphora mukul that has been used for thousands of years to treat arthritis, obesity, lipid metabolism disorders, hypothyroidism, and inflammation in the traditional Indian medicinal system. ${ }^{14}$ However, there is a possibility that adsorption of guggulsterone into the blood may induce serious adverse effects, even if guggulsterone is administered via an oral or rectal route. A possible solution to this critical drawback is the development of chemical derivatives. ${ }^{15}$ In this study, we report the design of novel guggulsterone derivatives and investigate the effect of these derivatives on TNF- $\alpha$-induced NF- $\kappa \mathrm{B}$ signaling in IECs and preventive and therapeutic murine models of dextran sulfate sodium (DSS)-induced colitis.

\section{MATERIALS AND METHODS Biosynthesis of Guggulsterone Derivatives and Cell Culture}

We synthesized four guggulsterone derivatives: GG-46, GG50B, GG-52, and GG-53 (Figure 1). Biosynthesis was performed at R\&D Center, Choongwae Pharma (Hwasung, Korea). The derivatives were dissolved in DMSO as a $50 \mathrm{mM}$ stock solution and stored at $-20^{\circ} \mathrm{C}$. The toxicity test of GG compounds was performed at ChemOn (Yongin, Korea). The human colon cancer cell line COLO 205 [KCLB 10222, Korean Cell Line Bank (KCLB), Seoul, Korea] was used between passages 20 and $40 .{ }^{16}$ Cells were grown in DMEM (Sigma, St Louis, MO, USA) supplemented with $10 \%$ fetal

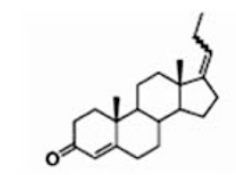

GG-46 (MW 312.49)

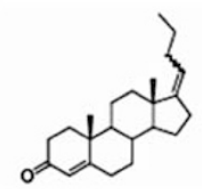

GG-52 (MW 326.52)

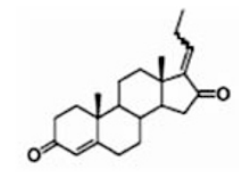

GG-50B (MW 326.47)

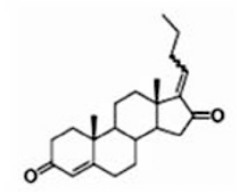

GG-53 (MW 340.50)
Figure 1 Chemical structure of novel guggulsterone derivatives. bovine serum, $2 \mathrm{mM}$ glutamine and antibiotics (100 unit $/ \mathrm{ml}$ of penicillin and $100 \mu \mathrm{g} / \mathrm{ml}$ of streptomycin). Cells were seeded at $0.5-2 \times 10^{6}$ cells per well onto six-well plates and allowed to attach overnight. After $12 \mathrm{~h}$ of serum starvation, cells were pretreated for $24 \mathrm{~h}$ with guggulsterone derivatives or with DMSO vehicle, after which cells were stimulated with TNF- $\alpha(10 \mathrm{ng} / \mathrm{ml})$ for the indicated period.

\section{Real-Time RT-PCR and ELISA}

Total cellular RNA was extracted from COLO 205 cells using Trizol (GIBCO BRL, Gaithersburg, MD, USA). Real-time PCR for IL-8, MCP- 1 , and $\beta$-actin mRNA was performed as described earlier. ${ }^{13,17}$ Briefly, $1 \mu \mathrm{g}$ of extracted RNA was reverse transcribed and amplified using the SYBR green PCR master mix and an ABI prism 7000 sequence detection system (Applied Biosystems, Foster City, CA, USA). Primers designed using Primer Express v2.0 were purchased from Applied Biosystems. ${ }^{13}$ Amplifications were performed in triplicate, and the data were normalized $v s \beta$-actin for human IL-8 or MCP-1. The amounts of human IL-8 and mouse macrophage-inflammatory protein (MIP)-2 were measured using a commercially available ELISA (R\&D Systems, Minneapolis, MN, USA) according to the manufacturer's instructions. Colonic tissues were homogenized with $0.3 \mathrm{ml}$ PBS containing complete protease inhibitor mixture (Roche, Tokyo, Japan). For measuring concentration of MIP-2, homogenates were centrifuged at $12000 \mathrm{~g}$ for $15 \mathrm{~min}$, and the supernatants were filtered through a $0.22-\mu \mathrm{m}$ filter to remove any contaminants. PathScan $\AA$ Phospho-NF- $\kappa$ B p 65 (Ser536) sandwich ELISA kit were purchased from Cell Signaling Technology (Danvers, MA, USA).

\section{Electrophoretic Mobility Shift Assay}

Cells were harvested and nuclear extracts were prepared as described earlier. ${ }^{18}$ The concentrations of proteins in the extracts were determined using a Bradford assay (Bio-Rad, Hercules, CA, USA). Electrophoretic mobility shift assay (EMSA) was performed using an assay kit (Promega, Madison, WI, USA) as described earlier. ${ }^{18}$ In brief, $5 \mu \mathrm{g}$ of nuclear extract was incubated for $30 \mathrm{~min}$ at room temperature with a $\gamma^{32} \mathrm{P}$-labeled oligonucleotide probe (5'-AGT TGA GGG GAC TTT CCC AGG C- $3^{\prime}$ ) corresponding to a consensus NF- $\kappa$ B-binding site. After incubation, both bound and free DNA was resolved on $5 \%$ polyacrylamide gels.

\section{Transfection and Reporter Assay}

Reporter plasmids, including pIL8-luciferase, p2x NF- $\kappa \mathrm{B}$ luciferase, $\mathrm{p} \beta$-actin- and $\mathrm{pRSV}-\beta$-galactosidase-luciferase transcriptional reporters, were provided by Dr Kagnoff of the University of California, San Diego, USA, ${ }^{18,19}$ and the pMCP-1-luciferase transcriptional reporter was provided by Dr Ik-San Kim at Seoul National University College of Medicine, Seoul, Korea. ${ }^{20,21}$ Cells in six-well dishes were transfected with $1.5 \mu \mathrm{g}$ of plasmid DNA using Lipofectamine Plus reagents (Invitrogen, Carlsbard, CA, USA) as described 
earlier. ${ }^{22}$ The transfected cells were incubated for $24 \mathrm{~h}$ at $37^{\circ} \mathrm{C}$ in a $5 \% \mathrm{CO}_{2}$ incubator. Cells were then harvested and wholecell lysates were prepared as described earlier. ${ }^{22}$ Luciferase activity was determined in accordance with the manufacturer's instructions (Tropix, Bedford, MA, USA) and luminescence was quantitated for $10 \mathrm{~s}$ using a luminometer (MicroLumat Plus, Berthold GmbH KG, Bad Wildbad, Germany). Luciferase activity was determined and normalized relative to $\beta$-galactosidase expression. ${ }^{22}$

\section{Immunoblot Analysis}

Cells were washed with ice-cold PBS and lysed in $0.5 \mathrm{ml} /$ well lysis buffer $[150 \mathrm{mM} \mathrm{NaCl}, 20 \mathrm{mM}$ Tris at $\mathrm{pH} 7.5,0.1 \%$ Triton X-100, $1 \mathrm{mM}$ phenylmethyl sulfonyl fluoride (PMSF), and $10 \mu \mathrm{g} / \mathrm{ml}$ aprotinin]. A measure of $15-50 \mu \mathrm{g}$ of protein per lane was size fractionated on a $6 \%$ polyacrylamide minigel, and electrophoretically transferred to a nitrocellulose membrane $(0.1-\mu \mathrm{m}$ pore size). Specific proteins were detected using mouse $\mathrm{I} \kappa \mathrm{B} \alpha$, anti-human phospho-I $\kappa \mathrm{B} \alpha$ and actin (Cell Signaling Technology, Beverly, MA, USA) as primary antibodies and peroxidase-conjugated anti-mouse IgG as a secondary antibody. Specifically bound peroxidase was detected by enhanced chemiluminescence (ECL system; Amersham Life Science, Buckinghamshire, UK) and exposure to X-ray film.

\section{IÆB Kinase Assay}

I $\kappa \mathrm{B}$ kinase (IKK) activity on $\mathrm{I} \kappa \mathrm{B} \alpha$ phosphorylation was determined by using a commercially available HTScan IKK- $\beta$ kinase assay kit (Cell Signaling Technology) according to the manufacturer's instructions. Briefly, cells treated with guggulsterone derivatives were washed with ice-cold PBS. Whole-cell extracts were prepared using lysis buffer $(150 \mathrm{mM}$ $\mathrm{NaCl}, 20 \mathrm{mM}$ Tris at pH 7.5, 0.1\% Triton X-100, 1 mM PMSF, and $10 \mu \mathrm{g} / \mathrm{ml}$ aprotinin), after which lysates were cleared by centrifugation at 14000 r.p.m. for $10 \mathrm{~min}$ at $4^{\circ} \mathrm{C}$. Levels of IKK activity were measured by colorimetric ELISA as per the manufacturer's instructions. ${ }^{23}$

\section{The Preventive Model of Acute Murine Colitis}

Animal studies were performed using specific pathogen-free mice as described earlier. ${ }^{13}$ Specific pathogen-free mice (C57BL/6NCrljBgi mice, 20-25 g, 7-8 weeks) were purchased from Orient Experimental Animal, Seoungnam, Korea. Animals were maintained on a 12 -h light/12-h dark cycle under the specific pathogen-free conditions. The mice had ad libitum access to a standard diet and water until reaching the desired age (8-9 weeks) and/or weight (18-21 g). All procedures using animals were reviewed and approved by the Institutional Animal Care and Use Committee of Seoul National University Hospital.

In vivo studies using a preventive murine model were performed as described earlier. ${ }^{13}$ Mice were administered $4 \%$ DSS (MP Biochemicals, Irvine, CA, USA) dissolved in water that was filter-purified for 5 days. The guggulsterone derivatives GG-50B and GG-52 were suspended in $0.5 \%$ methylcellulose solution (vehicle) and administered once daily by oral gavage ( 50 or $200 \mathrm{mg} / \mathrm{kg} /$ day) for 7 days beginning 2 days before DSS exposure. As a negative control, DSStreated mice received the vehicle in a comparable volume $(10 \mathrm{ml} / \mathrm{kg}$ ) by the same route. In the next step, to compare the effect of guggulsterone derivative GG-52 with well-known IBD drugs, sulfasalazine (Sigma, $200 \mathrm{mg} / \mathrm{kg} /$ day), prednisolone (Sigma, $1 \mathrm{mg} / \mathrm{kg} /$ day), and GG-52 (200 mg/kg/day) were administered once daily by oral gavage for 7 days beginning 2 days before DSS exposure. As there was no difference in water intake between the different treatment groups, the mice seemed to drink the same amount of DSS.

\section{The Therapeutic Model of Acute Murine Colitis}

To examine whether GG-52 can show the therapeutic effect on DSS-induced colitis, a therapeutic murine model was used as described earlier. ${ }^{24}$ Briefly, mice were given $4 \%$ DSS for 5 days to establish acute colitis, after which the guggulsterone derivative GG-52 suspended in $0.5 \%$ methylcellulose solution (vehicle) was administered once daily by the rectal route ( 25 or $100 \mathrm{mg} / \mathrm{kg} /$ day) for 3 days.

\section{TNBS-Induced Acute Murine Colitis}

Trinitrobenzene sulphonic acid (TNBS)-induced experimental colitis was performed in C57BL/6 mice as described earlier. ${ }^{25}$ In brief, mice were anesthetized with zoletil, and a $3.5 \mathrm{~F}$ catheter was inserted intrarectally $4 \mathrm{~cm}$ from the anus. To induce colitis, $100 \mu \mathrm{l}$ of $3 \mathrm{mg}$ TNBS (Sigma) in 50\% ethanol was slowly administered into the lumen via the catheter. GG-52 was suspended in 0.5\% methylcellulose solution (vehicle) and administered once daily by oral gavage ( $200 \mathrm{mg} / \mathrm{kg} /$ day) for 7 days beginning 2 days before TNBS exposure. As a negative control, mice received the vehicle in a comparable volume by the same route.

\section{Macroscopic Assessment and Histological Evaluation of Colonic Damage}

Mice were checked daily for behavior, water/food consumption, body weight, stool consistency, and the presence of gross blood in the stool or at the anus. After the animals were killed, colonic damage was quantified by a clinical score assessing weight loss, stool consistency, and gross rectal bleeding according to Cooper $e t$ al. $^{26}$ The disease activity index (DAI) was calculated based on the following parameters as described earlier: ${ }^{24}$ stool consistency (0, normal; 2, loose; 4 , diarrhea), gross bleeding ( 0 , absence; 2 , blood tinged; 4 , presence), and weight loss ( 0 , none; $1,1 \% \sim 5 \% ; 2,5 \% \sim 10 \%$; $3,10 \% \sim 20 \%$; 4 , more than $20 \%)$. DAI $=($ stool consistency + gross bleeding + weight loss)/3. For each animal, histological examination was performed on three samples of the distal colon. In DSS-induced colitis, all histological quantification was performed in a blinded manner using the scoring system described earlier. ${ }^{27}$ Briefly, three independent parameters 
were measured: the severity of inflammation, the extent of injury, and crypt damage. The score of each parameter was multiplied by a factor reflecting the percentage of tissue involvement, and all numbers were summed. In TNBSinduced colitis, inflammation was graded from 0 to 4 as follows in a blinded manner: 0 , no signs of inflammation; 1 , low leukocyte infiltration; 2, moderated leukocyte infiltration; 3, high leukocyte infiltration, moderate fibrosis, high vascular density, thickening of the colon wall, moderate goblet cell loss, and focal loss of crypts; and 4, transmural infiltrations, massive loss of goblet cells, extensive fibrosis, and diffuse loss of crypts. ${ }^{28}$

\section{Immunohistochemical Analysis}

Immunohistochemical analysis for phosphorylated IKK $\alpha$ was performed as described earlier. ${ }^{13}$ Briefly, for the microwave antigen retrieval procedure, slides were immersed in $10 \mathrm{mM}$ citrate buffer ( $\mathrm{pH}$ 6.0) in a clean polyethylene chamber in a full-powered microwave for $10 \mathrm{~min}$ and were then cooled for 10-20 min. After washing with PBS, the sections were stained with rabbit polyclonal antiphosphorylated IKK $\alpha$ antibody (Cell Signaling Technology) in an automated staining system (Tech Mate 1000 TM, Ventana, Tucson, AZ, USA) according to the manufacturer's recommendations. ${ }^{13}$

\section{Statistical Analysis}

Differences between groups were compared using an analysis of variance with Bonferroni correction. $P$-values $<0.05$ were considered statistically significant.

\section{RESULTS}

\section{The Guggulsterone Derivatives GG-50B and GG-52} Inhibit the Expression of IL-8 and MCP-1 in COLO 205 Cells

To determine whether guggulsterone derivatives could reduce inflammatory responses, chemokine mRNA expression was evaluated in COLO 205 cells stimulated with TNF- $\alpha$. As shown in Figure $2 \mathrm{a}$ and $\mathrm{b}$, pretreatment with the guggulsterone derivatives GG-50B and GG-52 significantly downregulated mRNA levels of IL-8 and MCP-1 in COLO 205 cells stimulated with TNF- $\alpha$, as assessed by real-time RT-PCR. In contrast, GG-46 and GG-53 did not significantly alter the upregulation of chemokine expression induced by TNF- $\alpha$ stimulation. Consistent with this, significant inhibition of IL-8 release by GG-50B $(50 \mu \mathrm{M})$ and GG-52 $(50 \mu \mathrm{M})$ was observed in TNF- $\alpha$-stimulated COLO 205 cells (Figure 2c). Inhibition of the expression of each chemokine was dependent on the concentration of GG-50B and GG-52, because the promoter activity in the COLO 205 cells transfected with IL-8 or MCP-1 promoter plasmid was correlated with the concentrations of the guggulsterone derivatives (Figure 3).

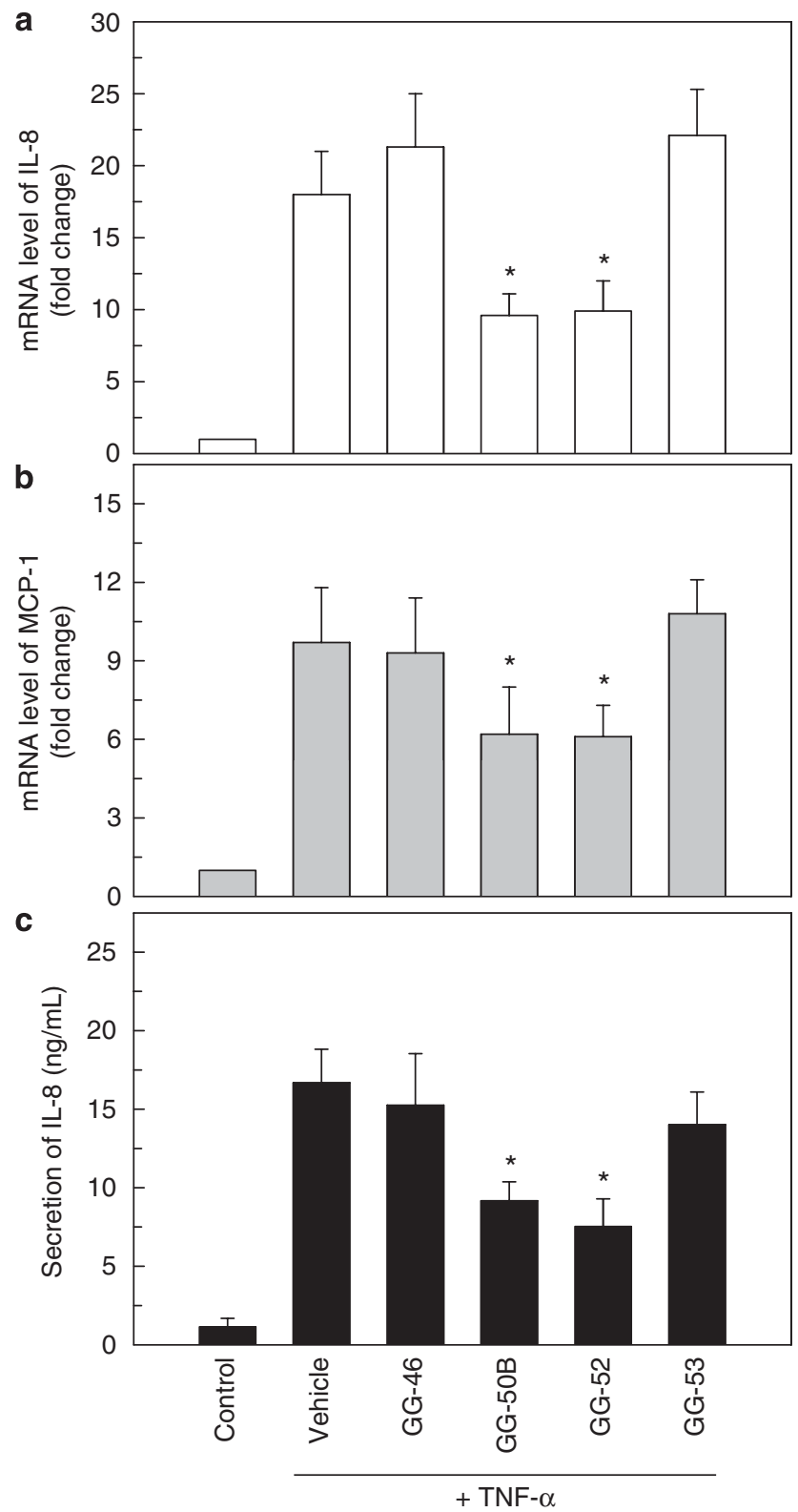

Figure 2 Effects of the guggulsterone derivatives on chemokine expression in COLO 205 cell stimulated with TNF- $\alpha$. COLO 205 cells were pretreated with $50 \mu \mathrm{M}$ of the guggulsterone derivatives GG-46, GG-50B, GG52 , and GG-53 for $24 \mathrm{~h}$ and then stimulated with TNF- $\alpha(10 \mathrm{ng} / \mathrm{ml})$ for $4 \mathrm{~h}$. mRNA expression of IL-8 (a) and MCP-1 (b) was measured by real-time RTPCR. Levels are normalized to $\beta$-actin. Data are expressed as fold change in mRNA transcript levels relative to the unstimulated control (mean \pm s.e.m., $n=3$ ). (c) COLO 205 cells were pretreated with the guggulsterone derivatives $(50 \mu \mathrm{M})$ for $24 \mathrm{~h}$ and then stimulated with TNF- $\alpha(10 \mathrm{ng} / \mathrm{ml})$ for $24 \mathrm{~h}$. Secretion of IL- 8 was measured by ELISA (mean \pm s.e.m., $n=5$ ). ${ }^{*} P<0.05$ compared with TNF- $\alpha$ alone.

Guggulsterone Derivatives GG-50B and GG-52 Suppress NF- $\kappa$ B Activity in TNF- $\alpha$-Stimulated COLO 205 Cells Expression of IL- 8 and MCP-1 mRNA is regulated primarily by the transcription factor NF- $\kappa \mathrm{B}$ in TNF- $\alpha$-stimulated 


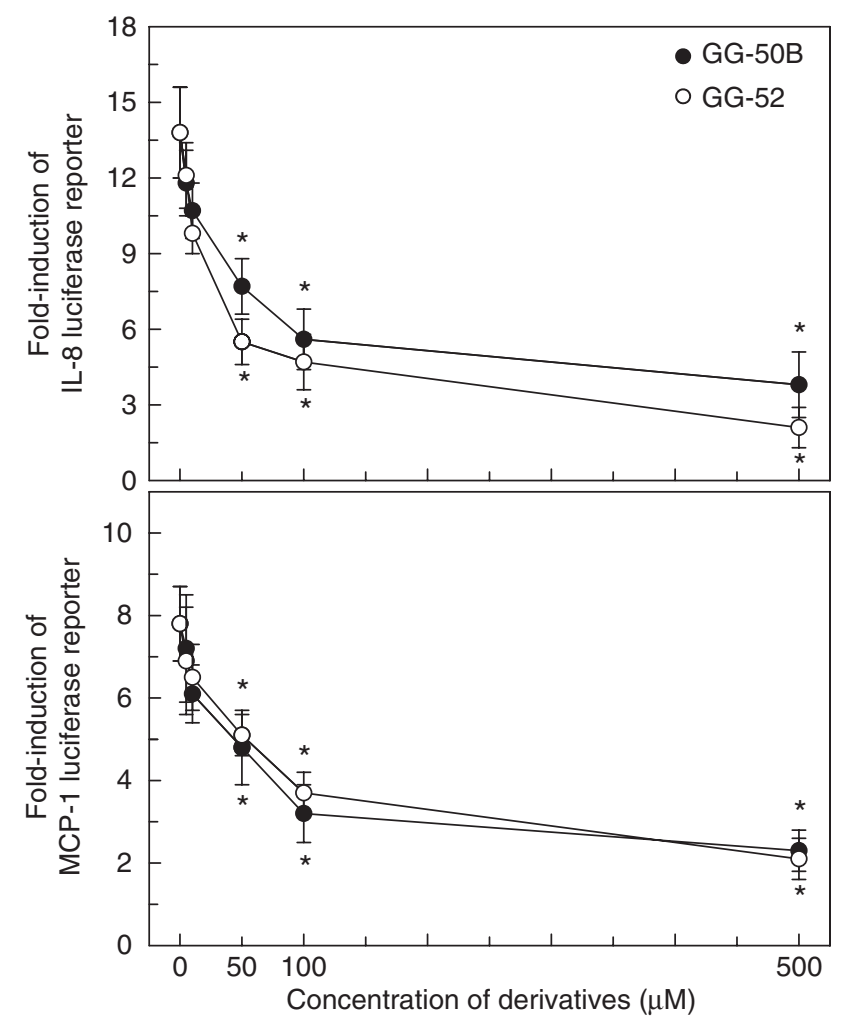

Figure 3 Effects of guggulsterone derivatives on reporter gene activation in COLO 205 cells stimulated with TNF- $\alpha$. COLO 205 cells were transfected with pIL8- or pMCP-1-luciferase transcriptional reporter, as indicated. After $24 \mathrm{~h}$, transfected cells were pretreated with the indicated concentration of GG-50B or GG-52 for $24 \mathrm{~h}$ and were then combined with TNF- $\alpha(10 \mathrm{ng} / \mathrm{ml})$ for $4 \mathrm{~h}$. Data are expressed as mean-fold induction \pm s.e.m. of luciferase activity relative to unstimulated controls $(n=5)$. The mean-fold induction of $\beta$-actin reporter gene activity relative to the unstimulated controls remained relatively constant throughout each experiment. ${ }^{\star} P<0.05$ compared with TNF- $\alpha$ alone.

IECs. ${ }^{29}$ As we already showed that guggulsterone inhibits NF- $\kappa \mathrm{B}$ activity in IECs, we asked whether the guggulsterone derivatives GG-50B and GG-52 could prevent TNF- $\alpha$ induced NF- $\kappa \mathrm{B}$ activity. For this experiment, the NF- $\kappa \mathrm{B}$ DNA-binding activity was determined by EMSA. Pretreatment with GG-50B and GG-52 reduced the NF- $\kappa$ B DNAbinding activity in a dose-dependent manner (Figure 4a). To confirm this result, a reporter gene assay was performed. As shown in Figure $4 \mathrm{~b}$, pretreatment of cells with GG-50B and GG-52 decreased the TNF- $\alpha$-induced NF- $\kappa$ B activity significantly.

\section{Guggulsterone Derivatives GG-50B and GG-52 Inhibit NF- $\kappa$ B Signaling in IEC by Blocking IKK}

TNF- $\alpha$ strongly induced $\mathrm{I} \kappa \mathrm{B} \alpha$ phosphorylation/degradation in COLO 205 cells, whereas $\mathrm{I} \kappa \mathrm{B} \alpha$ phosphorylation/degradation was suppressed in GG-50B and GG-52-treated cells (Figure 5a). To determine the effect of the two guggulsterone derivatives on IKK activity, an HTScan IKK- $\beta$ kinase assay

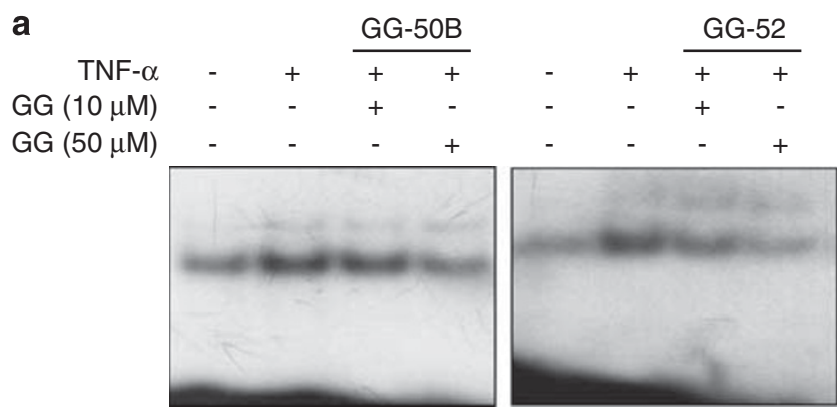

b

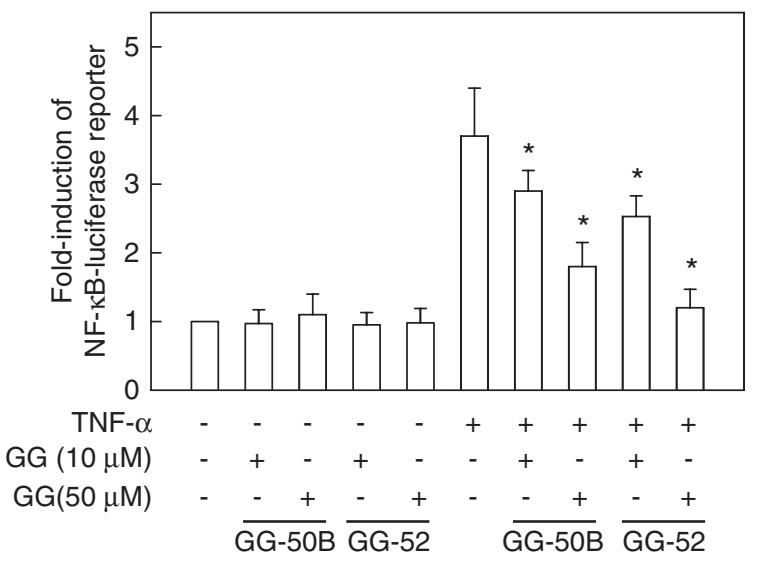

Figure 4 Guggulsterone derivatives GG-50B and GG5 inhibit NF- $\kappa$ B DNAbinding activity in COLO 205 cells stimulated with TNF- $\alpha$. (a) COLO 205 cells were pretreated with the guggulsterone derivatives GG-50B and GG-52 (10 or $50 \mu \mathrm{M})$ for $24 \mathrm{~h}$ and then stimulated with TNF- $\alpha(10 \mathrm{ng} / \mathrm{ml})$ for $1 \mathrm{~h}$. NF- $\kappa \mathrm{B}$ DNA-binding activity in the nuclear extracts was assessed by EMSA. The data are representative of more than five independent experiments. (b) COLO 205 cells were transfected with $2 \times$ pNF- $\kappa$ B-luciferase transcriptional reporter. After $24 \mathrm{~h}$, the transfected cells were pretreated with the indicated concentrations of GG-50B or GG-52 for $24 \mathrm{~h}$ and were then combined with TNF- $\alpha(10 \mathrm{ng} / \mathrm{ml})$ for $1 \mathrm{~h}$. Data are expressed as mean-fold induction \pm s.e.m. of luciferase activity relative to unstimulated controls $(n=5)$. The mean fold induction of the $\beta$-actin reporter gene activity relative to the unstimulated controls remained relatively constant throughout each experiment. ${ }^{*} P<0.05$ compared with TNF- $\alpha$ alone.

was performed. As shown in Figure 5b, stimulation of COLO 205 cells with TNF- $\alpha$ resulted in an increase of IKK activity, whereas pretreatment of cells with GG-50B or GG-52 significantly reduced the TNF- $\alpha$-induced IKK activity. These results indicate that the guggulsterone derivatives GG-50B and GG-52 can inhibit NF- $\kappa$ B signaling pathway by blocking IKK activity.

\section{The Guggulsterone Derivative GG-52 Ameliorates DSS-Induced Acute Colitis in a Preventive Murine Model} To test the physiological relevance of guggulsterone derivative-mediated suppression of inflammatory reactions in vivo, we used a murine model of DSS-induced acute colitis. Administration of DSS induced experimental colitis, characterized by weight loss, a shortened colon, and a high-DAI value, in mice. In this model, administration of GG-50B $(50 \mathrm{mg} / \mathrm{kg}$ q.d. or $200 \mathrm{mg} / \mathrm{kg}$ q.d.) did not significantly reduce the 
a

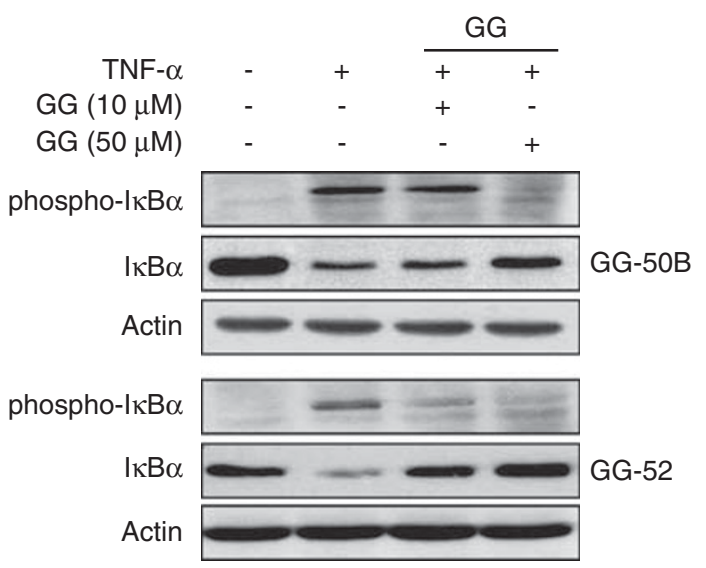

b

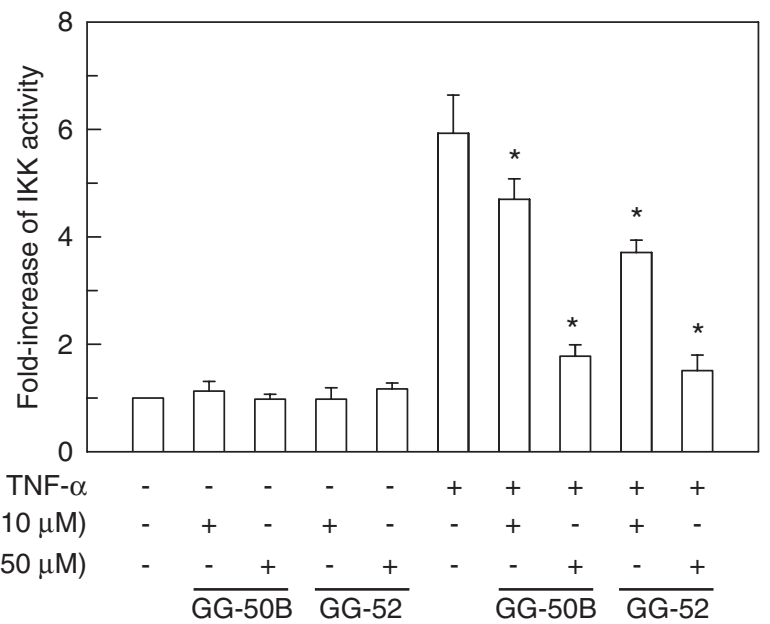

Figure 5 Effects of guggulsterone derivatives GG-50B and GG5 on $1 \kappa \mathrm{B} \alpha$ phosphorylation and IKK activity in COLO 205 cells stimulated with TNF- $\alpha$. COLO 205 cells were pretreated with the guggulsterone derivatives GG-50B and GG-52 (10 or $50 \mu \mathrm{M})$ for $24 \mathrm{~h}$ and then stimulated with TNF- $\alpha(10 \mathrm{ng} / \mathrm{ml})$ for $30 \mathrm{~min}$. (a) Immnoblot analysis for phospho- $|\kappa \mathrm{B} \alpha,| \kappa \mathrm{B} \alpha$ and actin was performed. The data are representative of more than three independent experiments. (b) IKK kinase activity was measured using the HTScan IKK- $\beta$ kinase assay kit. Data are expressed as mean-fold induction \pm s.e.m. of kinase activity relative to untreated controls $(n=5) .{ }^{*} P<0.05$ compared with TNF- $\alpha$ alone.

severity of DSS-induced colitis, although a few indices showed improvement (Table 1). In addition, administration of GG-50B did not reduce the microscopic histological grading (Figure 6a). In contrast, GG-52 (200 mg/kg q.d.) reduced both clinical and macroscopic inflammatory indices significantly (Table 1), and resulted in clear and significant attenuation of acute colitis histologically (Figure 6a and b). Furthermore, the DSS-induced phospho-NF- $\kappa$ B p 65 and secretion of MIP-2, a mouse homologue of IL-8, were significantly decreased in the GG-52-pretreated mice (Figure 7a and $b$ ).

As our data of in vitro study showed that GG-52 could exert its anti-inflammatory effects by blocking IKK activity in IEC, we investigated this signaling in DSS-colitis model to reconfirm it in vivo. To determine IKK activity in the in vivo
Table 1 Effects of guggulsterone derivatives on clinical indices of colonic inflammation in the preventive murine model

\begin{tabular}{lccc}
\hline & $\begin{array}{c}\text { Body weight } \\
\text { change (\%) }\end{array}$ & $\begin{array}{c}\text { Colon length to } \\
\text { weight ratio } \\
\text { (cm/g) }\end{array}$ & $\begin{array}{c}\text { Disease } \\
\text { activity } \\
\text { index }\end{array}$ \\
\hline Vehicle (control) & $100.8 \pm 1.4$ & $0.49 \pm 0.03$ & - \\
DSS & $81.6 \pm 6.4$ & $0.39 \pm 0.03$ & $3.0 \pm 0.6$ \\
DSS+GG-50B (50 mg/kg) & $90.3 \pm 5.7^{*}$ & $0.42 \pm 0.04$ & $1.0 \pm 0.9^{*}$ \\
DSS+GG-50B (200 mg/kg) & $85.3 \pm 4.5$ & $0.44 \pm 0.02$ & $1.8 \pm 1.1$ \\
DSS+GG-52 $(50 \mathrm{mg} / \mathrm{kg})$ & $90.9 \pm 2.5^{*}$ & $0.44 \pm 0.03$ & $1.8 \pm 0.8$ \\
DSS+GG-52 $(200 \mathrm{mg} / \mathrm{kg})$ & $94.3 \pm 1.2^{*}$ & $0.45 \pm 0.02^{*}$ & $1.3 \pm 0.6^{*}$
\end{tabular}

Data represent mean \pm s.d. $(n=6) .{ }^{*}<<0.05$ compared with DSS alone.

model of colitis, immunohistochemistry was performed on colon sections for the mice. As shown in Figure 7b, DSS colitis was accompanied by an increased expression of phophorylated IKK in the colonic mucosa and submucosa. In contrast, IKK phosphorylation was markedly reduced in the presence of GG-52 (Figure 7c).

\section{The Guggulsterone Derivative GG-52 Attenuates Acute Colitis in a Therapeutic Murine Model}

As our earlier results showed that the guggulsterone derivative GG-52 can prevent the induction of colitis by DDS, we next asked whether GG-52 could improve preformed DSSinduced colitis. For this experiment, GG-52 was administered via the rectal route. As shown in Table 2, administration of GG-52 (100 mg/kg q.d.) attenuated clinical indices such as body weight change, colon length, and DAI significantly.

\section{The Guggulsterone Derivative GG-52 Ameliorates TNBS-Induced Acute Murine Colitis}

We used a murine model of TNBS-induced acute colitis to confirm anti-inflammatory effect of GG-52 on intestinal mucosa. As shown in Table 3, administration of TNBSinduced experimental colitis that was characterized by increased clinical indices of colonic inflammation such as body weight changes and DAI. In this experimental model, pretreatment of GG-52 significantly reduced clinical indices in TNBS-treated mice. In addition, GG-52 resulted in a significant attenuation of acute colitis histologically (Figure 8a and $b$ ).

\section{Comparison of the Preventive Effects of GG-52, Sulfasalazine, and Prednisolone in DSS-Induced Acute Colitis}

We next asked how efficiently administration of GG-52 to prevent DSS-induced experimental colitis compared with well-known drugs used to treat IBD. For this experiment, a preventive murine model was used. As shown in Table 4, 

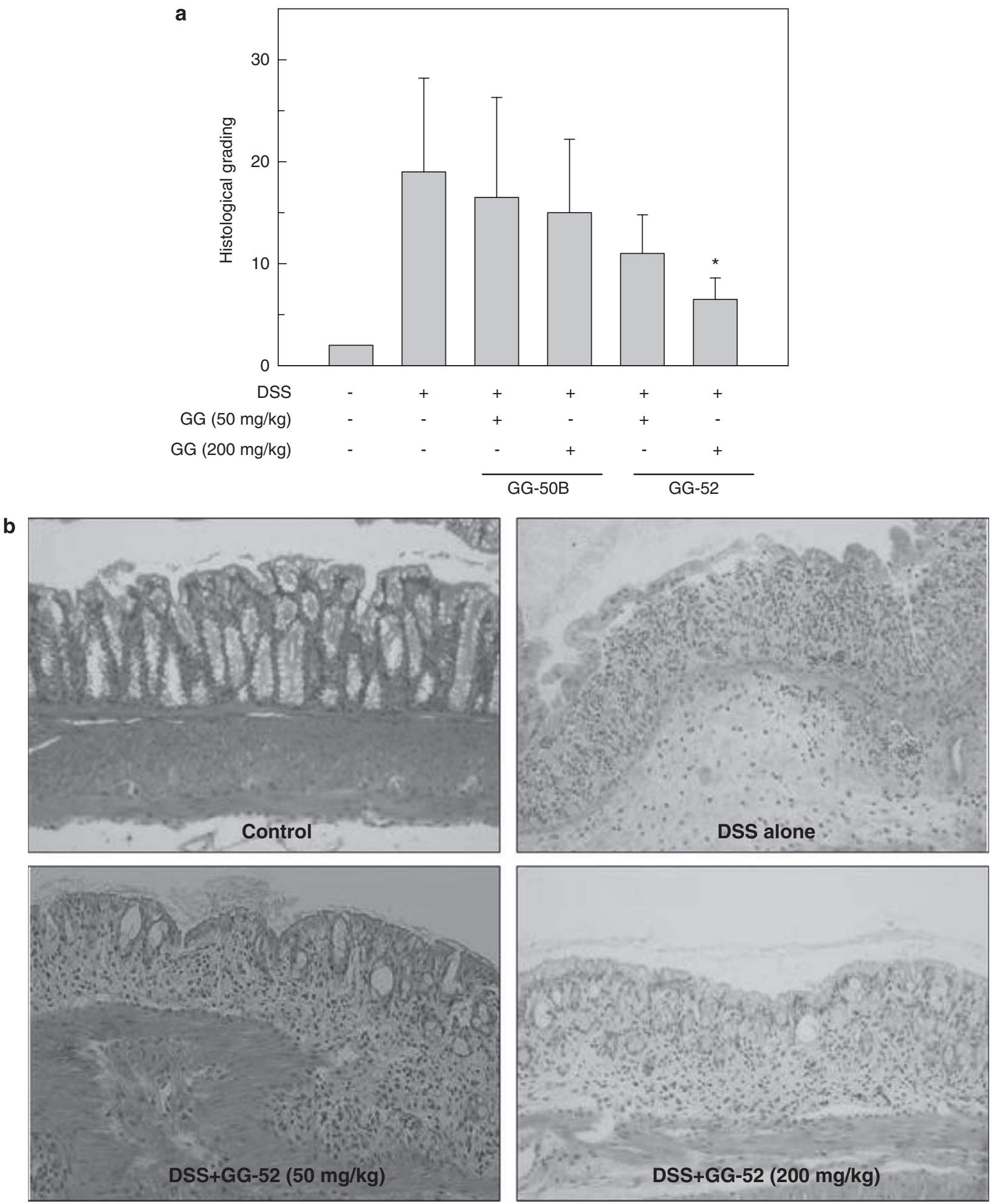

Figure 6 Histological evaluation of colitis in mice treated with guggulsterone derivatives. (a) Histologic score of colitis in the preventive model. Mice were treated with vehicle (control), dextran sulfate sodium (DSS), or DSS and guggulsterone derivatives GG-50B or GG-52, as described in the preventive model section of Materials and methods. The total histologic score was derived from the severity and extent of total inflammation and crypt damage (mean \pm s.d.). ${ }^{\star} P<0.05$ compared with DSS alone. (b) Histology of hematoxylin-eosin stains $(\times 100)$. Colonic samples were obtained from mice that received vehicle (negative control), DSS alone (positive control), or DSS + GG-52 (50 or $200 \mathrm{mg} / \mathrm{kg}$ q.d.). The colons of DSS-treated mice showed complete destruction of the epithelial architecture with loss of crypts and epithelial integrity, submucosal edema, and intense inflammatory cellular infiltration in all layers. Treatment with GG-52 attenuated this morphologic damage. 

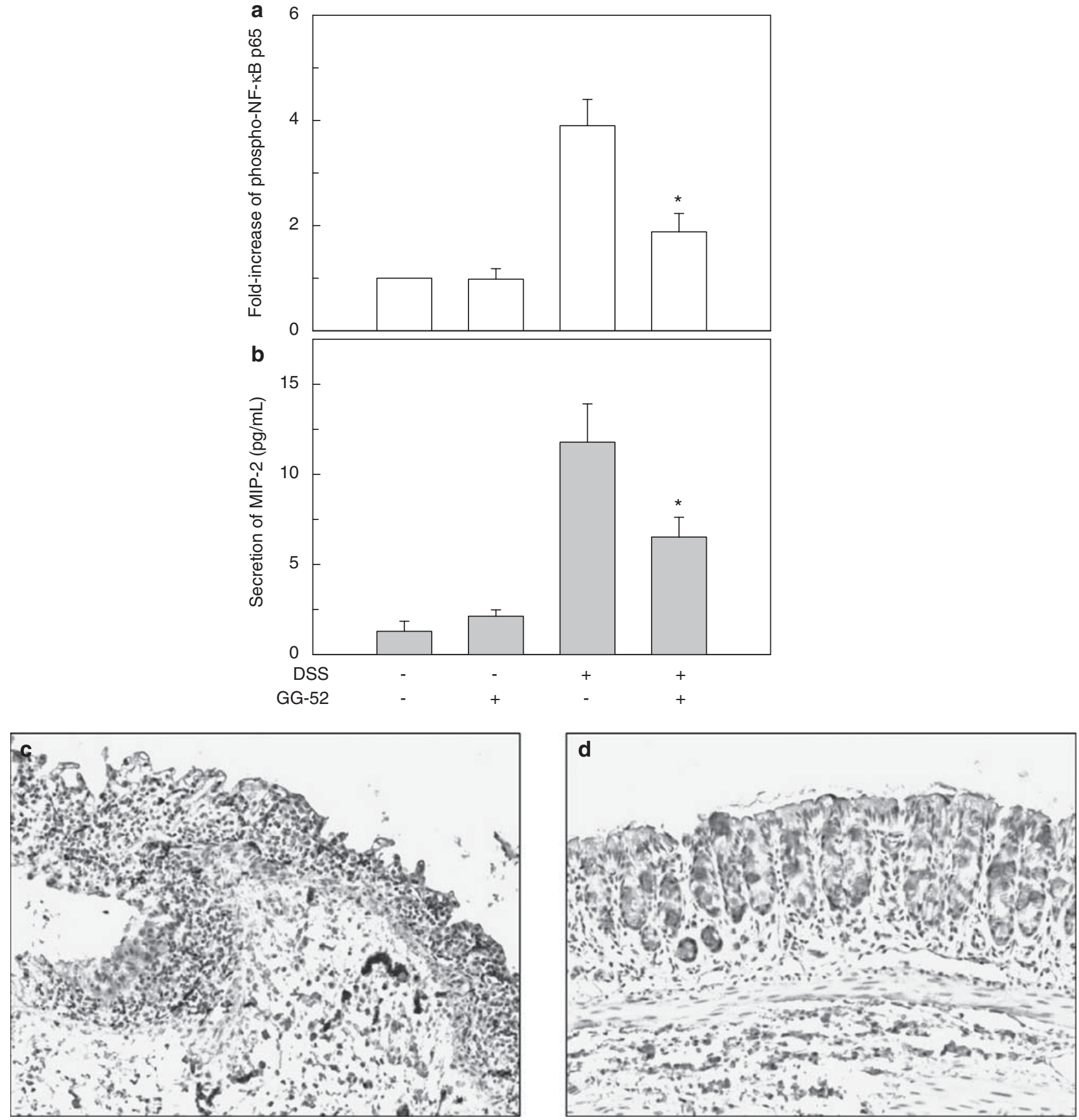

Figure 7 Guggulsterone derivative GG-52 attenuates NF- $\kappa$ B signals and MIP-2 secretion in dextran sulfate sodium (DSS)-induced colitis in mice. ( $\mathbf{a}$ and $\mathbf{b})$ Mice were treated with vehicle (control), DSS, or DSS + guggulsterone derivative GG-52 (200 mg/kg q.d.), as described in the preventive model section of Materials and methods. Levels of phospho-NF- $\kappa$ B p65 (a) and MIP-2 (b) were analyzed by ELISA. Data of phospho-NF- $\kappa$ B p65 are expressed as mean-fold induction \pm s.e.m. relative to untreated controls $(n=3)$. ${ }^{\star} P<0.05$ compared with DSS alone. Data of MIP-2 represent mean \pm s.e.m. ( $\mathrm{pg} / \mathrm{mg}$ tissue protein, $n=3$ ). (c and d) Histology (immunohistochemical staining for IKK; magnification, $\times 200$ ) of colonic samples taken from mice receiving DSS + PBS or DSS + GG-52 (200 mg/kg q.d.). To measure the activity of IKK in tissue sections, specimens were stained immunohistochemically with anti-phospho-IKK $\alpha$. In untreated mice with DSS-induced colitis, IKK $\alpha$ is heavily stained in both destructed epithelial cells and submucosal inflammatory cells (c). Treatment with GG-52 obviously attenuates the degree of phosphorylated IKK $\alpha$ staining in colon tissues (d). The results were representative of at least three separate examined sites. 
Table 2 Effects of guggulsterone derivatives on clinical indices of colonic inflammation in the therapeutic murine model

\begin{tabular}{lccc}
\hline & $\begin{array}{c}\text { Body weight } \\
\text { change (\%) }\end{array}$ & $\begin{array}{c}\text { Colon length to } \\
\text { weight ratio } \\
(\mathrm{cm} / \mathrm{g})\end{array}$ & $\begin{array}{c}\text { Disease } \\
\text { activity } \\
\text { index }\end{array}$ \\
\hline Vehicle (control) & $103.6 \pm 1.8$ & $0.42 \pm 0.02$ & - \\
DSS & $86.4 \pm 2.9$ & $0.33 \pm 0.02$ & $2.6 \pm 0.5$ \\
DSS+GG-52 $(25 \mathrm{mg} / \mathrm{kg})$ & $83.9 \pm 3.9$ & $0.34 \pm 0.04$ & $1.7 \pm 0.8$ \\
DSS+GG-52 $(100 \mathrm{mg} / \mathrm{kg})$ & $97.3 \pm 3.1^{*}$ & $0.38 \pm 0.01^{*}$ & $0.8 \pm 0.4^{*}$
\end{tabular}

Data represent mean \pm s.d. $(n=6) .{ }^{\star} P<0.05$ compared with DSS alone.
Table 3 Effects of guggulsterone derivative GG-52 on clinical indices of colonic inflammation in the TNBS-induced colitis murine model

\begin{tabular}{lccc}
\hline & $\begin{array}{c}\text { Body weight } \\
\text { change }(\%)\end{array}$ & $\begin{array}{c}\text { Colon length to } \\
\text { weight ratio } \\
\text { (cm/g) }\end{array}$ & $\begin{array}{c}\text { Disease } \\
\text { activity } \\
\text { index }\end{array}$ \\
\hline Vehicle (control) & $100.8 \pm 1.6$ & $0.49 \pm 0.03$ & - \\
TNBS & $78.5 \pm 4.8$ & $0.27 \pm 0.01$ & $2.75 \pm 0.4$ \\
TNBS+GG-52 (200 mg/kg) & $97.9 \pm 3.1^{*}$ & $0.31 \pm 0.03$ & $0.90 \pm 0.72^{*}$
\end{tabular}

Data represent mean \pm s.d. $(n=5) .{ }^{\star} P<0.05$ compared with TNBS alone.

retention period in the gut lumen, we designed guggulsterone derivatives with increased lipophilicity and decreased solubility, and then biosynthesized four new derivatives. Among the derivatives, GG-50B and GG-52 inhibited the expression of chemokines IL-8 and MCP-1 by the blockade of $\mathrm{NF}-\kappa \mathrm{B}$ signaling in IEC, suggesting a possible mechanism for their anti-inflammatory actions in the intestine. In this study, guggulsterone derivatives did not completely inhibit the NF- $\kappa \mathrm{B}$ activity in TNF- $\alpha$-stimulated cells. As the expression of chemokine IL- 8 and MCP-1 is regulated by transcriptional factor NF- $\kappa \mathrm{B}$ and $\mathrm{AP}-1$, it is possible that AP-1 signal may be involved in chemokine suppression in IECs treated with guggulsterone derivatives. Therefore, further study is needed to clarify whether AP-1 signaling is involved in chemokine suppression in guggulsterone derivatives-treated cells.

To clarify whether guggulsterone derivatives can modulate inflammation in the intestines of experimental animals, we used two murine preventive and therapeutic models of DSSinduced colitis; these models have several characteristics resembling those found in human ulcerative colitis and has proven useful for examining the pathophysiology underlying IBD. ${ }^{26,27}$ We showed that GG-52 could prevent DSS-induced acute colitis, whereas GG-50B partially improved the disease indices in colitis mice. In addition, GG-52 significantly attenuated the acute colitis in TNBS-induced experimental colitis. Furthermore, we showed that GG-52 ameliorated the established colitis in DSS-treated mice. In the next step, we studied acute toxicity of GG-52 in mice. Oral administration of GG-52 at a daily dose of $2000 \mathrm{mg} / \mathrm{kg}$ for 2 weeks did not result in any significant toxicity in mice. The value of no observed adverse effect level for GG-52 was $>2000 \mathrm{mg} / \mathrm{kg}$, that is, 10 times the maximum therapeutic dose. These results suggest that the guggulsterone derivative GG-52 has both protective and therapeutic effects on inflammation in the colon, indicating that it has a potential clinical value for the treatment of IBD. However, these findings should be further validated by studies using various different colitis models such as TNBS colitis and the IL-10 knock-out model, and chronic toxicity in mice. 
b

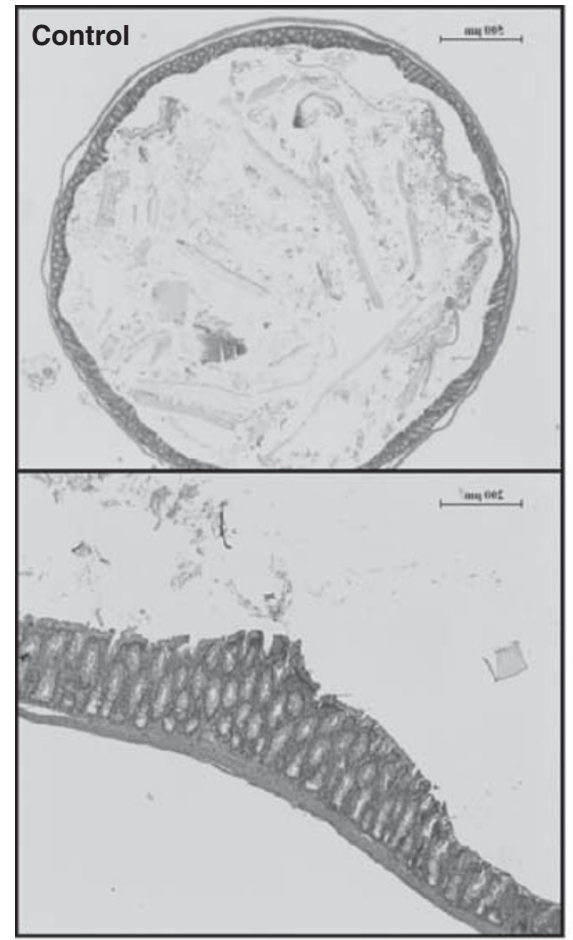

a

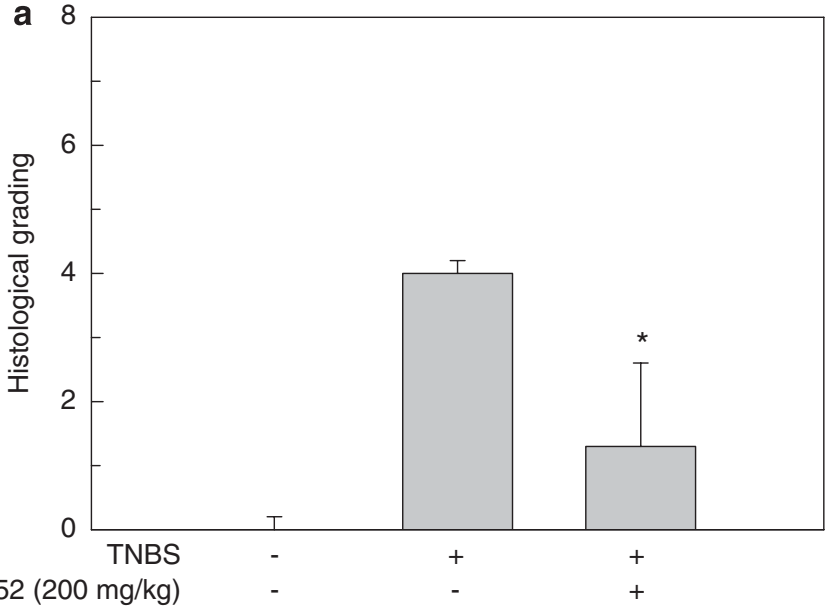

GG-52 $(200 \mathrm{mg} / \mathrm{kg}) \quad-\quad-\quad+$
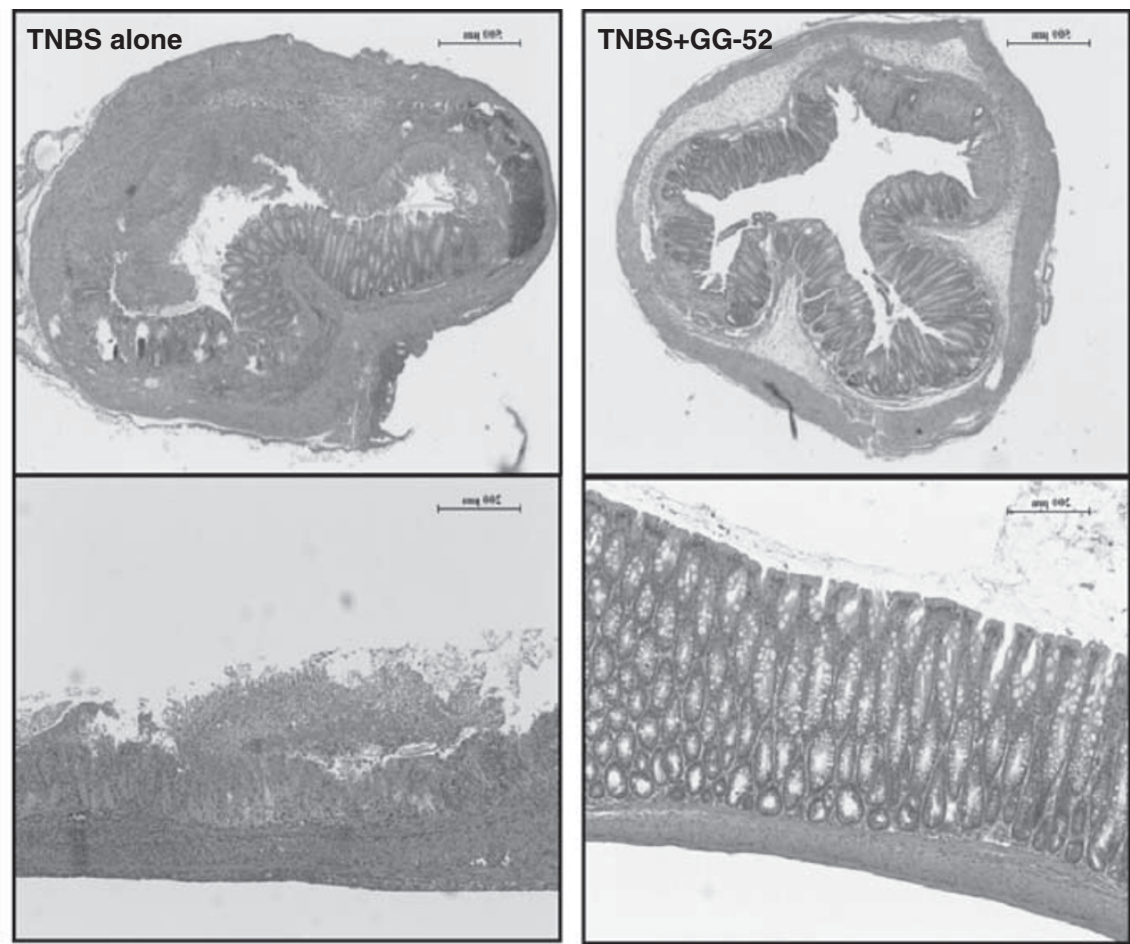

Figure 8 Histological evaluation of TNBS colitis in mice treated with a guggulsterone derivative GG-52. (a) Histologic score of TNBS colitis. Mice were treated with vehicle (control), TNBS, or TNBS + GG-52. The total histologic score was derived from the severity and extent of total inflammation and crypt damage (mean \pm s.d.). ${ }^{\star} P<0.05$ compared with TNBS alone. (b) Histology of hematoxylin-eosin stains. Colonic samples were obtained from mice that received vehicle (negative control), TNBS alone (positive control), or TNBS + GG-52 (200 mg/kg q.d.). The colons of TNBS-treated mice showed complete destruction of the epithelial architecture with loss of crypts and epithelial integrity, submucosal edema, and intense inflammatory cellular infiltration in all layers. Treatment with GG-52 attenuated this morphologic damage. Upper panels, cross-section $(\times 40)$; lower panels, longitudinal section $(\times 100)$.

As sulfasalzine and corticosteroids, which are generally used for the treatment of IBD, have been shown to inhibit NF- $\kappa$ B signaling, ${ }^{3-33}$ we evaluated how efficiently the guggulsterone derivative GG-52 could prevent DSS-induced experimental colitis compared with the former two drugs. We found that treatment with GG-52 has a comparable effect on the inhibition of colitis as sulfasalzine or prednisolone. Especially,
GG-52 and sulfasalazine/5-ASA might have common features in the action of mechanism and formulation: blockade of NF$\kappa \mathrm{B}$ signaling by targeting IKK and efficacy of topical administration. IKK can be related with the development of colitisassociated colon cancer $^{34}$ and sulfasalazine/5-ASA may reduce the risk of colorectal cancer in IBD patients. ${ }^{35}$ Thus, further investigation is needed for the chemoprevention of by GG-52. 
Table 4 Clinical indices in mice with DDS-induced colitis treated with GG-52, sulfasalzine, or prednisolone

\begin{tabular}{lccc}
\hline & $\begin{array}{c}\text { Body weight } \\
\text { change }(\%)\end{array}$ & $\begin{array}{c}\text { Colon length to } \\
\text { weight ratio } \\
\text { (cm/g) }\end{array}$ & $\begin{array}{c}\text { Disease } \\
\text { activity } \\
\text { index }\end{array}$ \\
\hline Vehicle (control) & $103.6 \pm 1.77$ & $0.42 \pm 0.02$ & - \\
DSS & $82.1 \pm 2.59^{\star}$ & $0.31 \pm 0.04^{*}$ & $3.0 \pm 0.0^{*}$ \\
Sulfasalazine $(200 \mathrm{mg} / \mathrm{kg})$ & $90.3 \pm 2.99^{\dagger}$ & $0.40 \pm 0.08^{\dagger}$ & $1.7 \pm 0.9^{\dagger}$ \\
Prednisolone $(1 \mathrm{mg} / \mathrm{kg})$ & $89.6 \pm 3.40^{\dagger}$ & $0.41 \pm 0.03^{\dagger}$ & $1.8 \pm 1.3$ \\
GG-52 $(200 \mathrm{mg} / \mathrm{kg})$ & $92.8 \pm 6.01^{\dagger}$ & $0.42 \pm 0.03^{\dagger}$ & $1.58 \pm 0.8^{\dagger}$
\end{tabular}

Data represent mean \pm s.d. $(n=6) .{ }^{*} P<0.05$ compared with control; ${ }^{\dagger} P<0.05$ compared with DSS alone.

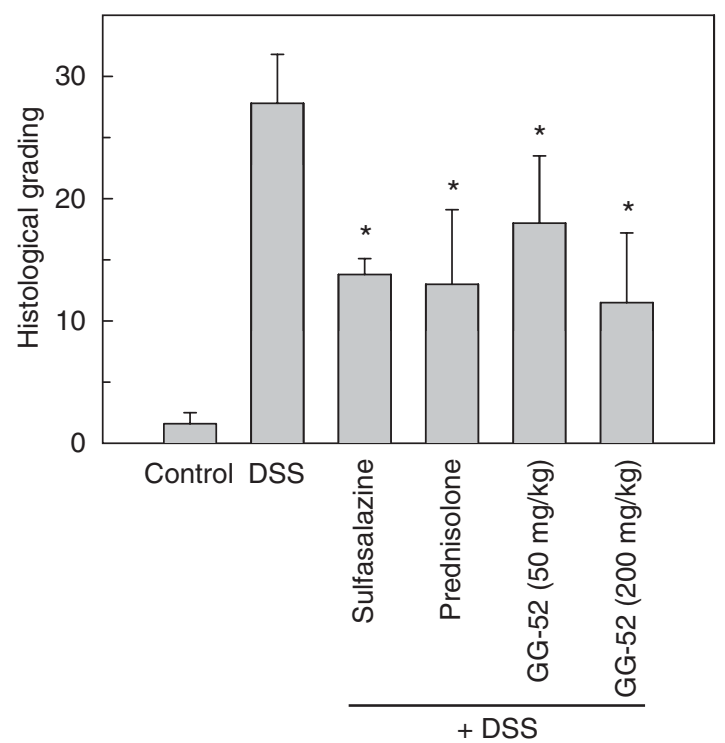

Figure 9 Histologic score of colitis in mice treated with sulfasalazine, prednisolone, or the guggulsterone derivative GG-52. Mice were treated with vehicle (control), DSS alone, or DSS and sulfasalazine (200 $\mathrm{mg} / \mathrm{kg}$ q.d.), DSS and prednisolone (1 $\mathrm{mg} / \mathrm{kg}$ q.d.), or DSS and the guggulsterone derivative GG-52 (50 or $200 \mathrm{mg} / \mathrm{kg}$ q.d.), as described in the preventive model section of Materials and methods. The total histologic score was derived from the severity and extent of total inflammation and crypt damage (mean \pm s.d.). ${ }^{*} P<0.05$ compared with DSS alone.

In conclusion, a novel guggulsterone derivative GG-52 suppresses NF- $\kappa \mathrm{B}$ signaling by targeting IKK and chemokine expression in IEC and attenuates intestinal inflammation in both preventive and therapeutic murine models. Therefore, GG-52 could be a potential therapeutic agent for the treatment of IBD.

\section{ACKNOWLEDGEMENTS}

We thank Dr Martin F Kagnoff and Dr Joseph A DiDonato for providing the reporter gene plasmids, Dr Ik-Sang Kim for the PMCP-1-luciferase plasmid, and Hong-Shik Yun for technical assistance. This work was supported by a grant from the Seoul R\&BD Program and the Basic Science Research Program through the National Research Foundation of Korea (NRF) funded by the Ministry of Education, Science and Technology (R11-2008-04401004-0).

\section{DISCLOSURE/CONFLICT OF INTEREST}

The authors declare no conflict of interest.

1. Braus NA, Elliott DE. Advances in the pathogenesis and treatment of IBD. Clin Immunol 2009;132:1-9.

2. McGuckin MA, Eri R, Simms LA, et al. Intestinal barrier dysfunction in inflammatory bowel diseases. Inflamm Bowel Dis 2008;15:100-113.

3. Isaacs KL, Lewis JD, Sandborn WJ, et al. State of the art: IBD therapy and clinical trials in IBD. Inflamm Bowel Dis 2005;11(Suppl 1):S3-S12.

4. Ma TY, Anderson JM. Tight junctions and intestinal barrier. In: Johnson LR (ed). Physiology of the Gastrointestinal Tract. Academic Press: New York, 2006, pp 1559-1594.

5. Caradonna L, Amati L, Magrone T, et al. Enteric bacteria, lipopolysaccharides and related cytokines in inflammatory bowel disease: biological and clinical significance. J Endotoxin Res 2000;6:205-214.

6. Chichlowski M, Hale LP. Bacterial-mucosal interactions in inflammatory bowel disease: an alliance gone bad. Am J Physiol Gastrointest Liver Physiol 2008;295:G1139-G1149.

7. McGuckin MA, Eri R, Simms LA, et al. Intestinal barrier dysfunction in inflammatory bowel diseases. Inflamm Bowel Dis 2009;15:100-113.

8. Neish AS. Molecular aspects of intestinal epithelial cell-bacterial interactions that determine the development of intestinal inflammation. Inflamm Bowel Dis 2004;10:159-168.

9. Atreya I, Atreya R, Neurath MF. NF- $\kappa$ B in inflammatory bowel disease. J Intern Med 2008;263:591-596.

10. Ma TY, Iwamoto GK, Hoa NT, et al. TNF-alpha-induced increase in intestinal epithelial tight junction permeability requires NF- $\kappa \mathrm{B}$ activation. Am J Physiol Gastrointest Liver Physiol 2004;286: G367-G376.

11. Jobin $C$, Sartor RB. NF- $\kappa$ B signaling proteins as therapeutic targets for inflammatory bowel diseases. Inflamm Bowel Dis 2000;6:206-213.

12. Neurath MF, Becker C, Barbulescu K. Role of NF- $k$ B in immune and inflammatory responses in the gut. Gut 1998;43:856-860.

13. Cheon JH, Kim JS, Kim JM, et al. Plant sterol guggulsterone inhibits nuclear factor- $\kappa \mathrm{B}$ signaling in intestinal epithelial cells by blocking $I \kappa \mathrm{B}$ kinase and ameliorates acute murine colitis. Inflamm Bowel Dis 2006;12:1152-1161.

14. Urizar NL, Moore DD. GUGULIPID: a natural cholesterol-lowering agent. Annu Rev Nutr 2003;23:303-313.

15. Terracciano $S$, Aquino $M$, Rodriquez $M$, et al. Chemistry and biology of anti-inflammatory marine natural products: molecules interfering with cyclooxygenase, NF- $\kappa \mathrm{B}$ and other unidentified targets. Curr Med Chem 2006;13:1947-1969.

16. Lee JY, Kim JS, Kim JM, et al. Simvastatin inhibits NF- $\kappa B$ signaling in intestinal epithelial cells and ameliorates acute murine colitis. Int Immunopharmacol 2007;7:241-248.

17. Kim JM, Kim JS, Lee LY, et al. Vacuolating cytotoxin in Helicobacter pylori water-soluble proteins upregulates chemokine expression in human eosinophils via $\mathrm{Ca} 2+$ influx, mitochondrial reactive oxygen intermediates, and NF- $\kappa$ B activation. Infect Immun 2007;75:3373-3381.

18. Kim JM, Oh YK, Kim YJ, et al. Polarized secretion of CXC chemokines by human intestinal epithelial cells in response to Bacteroides fragilis enterotoxin: NF- $\kappa$ B plays a major role in the regulation of IL-8 expression. Clin Exp Immunol 2001;123:421-427.

19. Elewaut $D$, DiDonato JA, Kim JM, et al. NF- $\kappa B$ is a central regulator of the intestinal epithelial cell innate immune response induced by infection with enteroinvasive bacteria. J Immunol 1999;163:1457-1466.

20. Cho NH, Seong SY, Huh MS, et al. Induction of the gene encoding macrophage chemoattractant protein 1 by Orientia tsutsugamushi in human endothelial cells involves activation of transcription factor activator protein 1. Infect Immun 2002;70:4841-4850.

21. Kim JM, Jung HY, Lee JY, et al. Mitogen-activated protein kinase and activator protein-1 dependent signals are essential for Bacteroides fragilis enterotoxin-induced enteritis. Eur J Immunol 2005;35: 2648-2657. 
22. Kim JM, Lee JY, Yoon YM, et al. Bacteroides fragilis enterotoxin induces cyclooxygenase-2 and fluid secretion in intestinal epithelial cells through NF- $\kappa$ B activation. Eur J Immunol 2006;36:2446-2456.

23. Lee JY, Kim H, Cha MY, et al. Clostridium difficile toxin A promotes dendritic cell maturation and chemokine CXCL2 expression through p38, IKK, and the NF- $\kappa$ B signaling pathway. J Mol Med 2009;87:169-180.

24. Nam SY, Kim JS, Kim JM, et al. DA-6034, a derivative of flavonoid, prevents and ameliorates dextran sulfate sodium-induced colitis and inhibits colon carcinogenesis. Exp Biol Med 2008;233:180-191.

25. Neurath MF, Fuss I, Kelsall BL, et al. Antibodies to interleukin 12 abrogate established experimental colitis in mice. J Exp Med 1995;182:1281-1290.

26. Cooper HS, Murthy SN, Shah RS, et al. Clinicopathologic study of dextran sulfate sodium experimental murine colitis. Lab Invest 1993;69:238-249.

27. Dieleman LA, Palmen MJ, Akol H, et al. Chronic experimental colitis induced by dextran sulphate sodium (DSS) is characterized by Th1 and Th2 cytokines. Clin Exp Immunol 1998;114:385-391.

28. Scheiffele F, Fuss IJ. Induction of TNBS colitis in mice. Curr Protoc Immunol 2002;Chapter 15: Unit 15.19.
29. May MJ, Ghosh S. Signal transduction through NF- $\kappa$ B. Immunol Today 1998;19:80-88.

30. Zhou W, Cao Q, Peng Y, et al. FoxO4 inhibits NF-kappaB and protects mice against colonic injury and inflammation. Gastroenterology; 137:1403-1414.

31. Weber CK, Liptay S, Wirth T et al. Suppression of NF- $\kappa$ B activity by sulfasalazine is mediated by direct inhibition of $I_{\kappa} B$ kinases alpha and beta. Gastroenterology 2000;119:1209-1218.

32. Bantel $H$, Berg $C$, Vieth $M$, et al. Mesalazine inhibits activation of transcription factor NF- $\kappa$ B in inflamed mucosa of patients with ulcerative colitis. Am J Gastroenterol 2000;95:3452-3457.

33. Auphan N, DiDonato JA, Rosette C, et al. Immunosuppression by glucocorticoids: inhibition of NF- $\kappa$ B activity through induction of I $\kappa$ B synthesis. Science 1995;270:286-290.

34. Greten FR, Eckmann L, Greten TF, et al. IKK $\beta$ links inflammation and tumorigenesis in a mouse model of colitis-associated cancer. Cell 2004;118:285-296.

35. Van Staa TP, Card T, Logan RF, et al. 5-Aminosalicylate use and colorectal cancer risk in inflammatory bowel disease: a large epidemiological study. Gut 2005;54:1573-1578. 